\title{
Integrated Water Resources Management, Efficient and Sustainable Water Systems, Protection and Restoration of the Environment
}

\author{
Vassilios A. Tsihrintzis ${ }^{1}$
}

Received: 20 August 2017 / Accepted: 20 August 2017 / Published online: 7 October 2017

(C) Springer International Publishing AG 2017

The current issue of Environmental Processes includes twenty papers originally presented in three conferences. Pre-selected papers by the conference organizers were expanded by the authors, and substantially different versions were prepared and submitted to the journal for peer-review according to the standards of the journal. Those that passed the peer-review process are included in this issue of the journal.

The first part contains extended versions of five papers, initially presented at the 3rd Common Conference (13th conference of the Hellenic Hydrotechnical Association, 9th conference of the Hellenic Committee on Water Resources Management, and 1st conference of the Hellenic Water Association) (http://3rd-conference.waterinfo.gr/). The conference theme was: "Integrated Water Resources Management in the New Era". This conference is a part of a conference series organized by the three scientific associations in Greece which deal with water resources and environmental management. The conferences are co-organized by the associations and one university in Greece. The current conference was organized and took place in the facilities of the School of Rural and Surveying Engineering of the National Technical University of Athens, Greece, from the 10th to the 12th of December, 2015. Conference co-chairmen were: Professor Vassilios A. Tsihrintzis (National Technical University of Athens, Greece), Professor Konstantinos Katsifarakis (Aritotle University of Thessaloniki) and Professor George Tsakiris (National Technical University of Athens, Greece). The conference topics included: Water resources management and engineering; Fluid mechanics - Hydraulics - Ecohydraulics - Fluvial hydraulics - Sediment transport; Urban drainage; Reclamation works; Hydrology - Ecohydrology; Watershed management Transboundary catchments; Climate change and water resources; Groundwater hydrology Hydrogeology; Ecological engineering - Protection, restoration and management of

Vassilios A. Tsihrintzis

tsihrin@otenet.gr; tsihrin@survey.ntua.gr; tsihrin@central.ntua.gr

1 Centre for the Assessment of Natural Hazards and Proactive Planning \& Laboratory of Reclamation Works and Water Resources Management, School of Rural and Surveying Engineering, National Technical University of Athens, 9 Iroon Polytechniou St., Zografou, 15780 Athens, Greece 
ecosystems - Wetlands; Protection and restoration of the coastal environment - Coastal zone management; Pollutant transport; Wastewater and solid waste management - Natural Treatment Systems - Constructed wetlands - Reuse; Potable water treatment technology; Environmental geotechnology; Water resources and environmental economics; Remote sensing - GIS; Mathematical modeling - Decision making methods; Monitoring of the environment; Legislation; and Education. 114 papers have been presented and included in the conference proceedings. Five papers passed the peer review process and are included in this issue. Professors Vassilios

A. Tsihrintzis and Konstantinos Katsifarakis acted as Guest Editors of these five papers. The topics dealt in these papers are briefly presented below:

Gkotsis et al. (2017) studied in batch experiments the control of membrane fouling in MBR treatment systems through the addition of several commercially available cationic (FO 4000 SSH and ADIFLOC series) and anionic (LT-25 Magnafloc) polyelectrolytes. Reversible fouling was assessed in terms of sludge filterability tests, whereas irreversible fouling was assessed in terms of Soluble Microbial Products concentration measurements. Cationic polyelectrolytes FO $4000 \mathrm{SSH}$ series and ADIFLOC series were able to reduce both reversible and irreversible fouling, and were found preferable compared to the anionic polyelectrolyte LT-25 Magnafloc.

Bloutsos et al. (2017) evaluated the concentration of heavy metals in surface water and groundwater in Alfeios River Basin at various sampling sites across the main river and its major tributaries, as well as several groundwater wells and boreholes near the river. The origin of the selected heavy metals was found rather natural in the river basin, with the exception of the anthropogenic contributions of $\mathrm{Pb}$ from Lousios river catchment and of $\mathrm{Fe}$ from the Megalopoli mine. Such data are useful for the evaluation of the water quality, a requirement in the implementation of River Basin Management Plans.

Trikoilidou et al. (2017) present computation of water quality indices (WQIs) in two natural lakes in Greece using an alternative to the National Sanitation Foundation WQI. The application was made at each sampling site and at the overall water body for comparison. The study showed that the use of WQIs proved to be good practice in evaluating and characterizing the water quality of lakes.

Kasiteropoulou et al. (2017) numerically studied turbulent flow in a vegetated open channel. Vegetation was modeled by a series of small diameter rigid cylinders protruding vertically from the channel bed. The ANSYS-CFX computer program was used to solve the partial differential equations based on the finite volume method. Several tests were made to reduce the computational burden and ensure that the solution is independent of the mesh used. The authors conclude that tremendous computational resources are required to achieve meshindependent solutions for such a complex geometry problem.

Zotou and Tsihrintzis (2017) estimated the water footprint (WF) of 42 crop species in the area of Mesogeia, Attiki, Greece. Evapotranspiration estimation was based on both the BlaneyCriddle and the Penman-Monteith methods. Results showed that olive trees and vineyards accounted for approximately $95 \%$ of the overall water consumption. The Blaney-Criddle method resulted in higher WF and water consumptions for the majority of the crops, compared to the Penman-Monteith method. The study showed that water footprint analysis can provide solutions to existing problems in water resources management through the demonstration of the water demanding crops and potentially erroneous agricultural practices.

This issue of Environmental Processes also presents a collection of nine papers initially presented at the 2nd EWaS International Conference under the theme "Efficient \& Sustainable Water Systems toward Worth Living Development". The conference was held from June 1 to 4, 
2016, in Platanias, Chania, Crete, Greece (http://www.ewas2.tuc.gr/), and was co-organized by the University of Thessaly/Civil Engineering Department and the Technical University of Crete/School of Environmental Engineering (Co-chairmen: V. Kanakoudis-University of Thessaly, G. Karatzas-Technical University of Crete; vice-chairman: E. KeramarisUniversity of Thessaly). The conference highlighted the need to improve the efficiency and sustainability of all water systems in a changing and fragile environment, especially under the difficult economic conditions people are facing today. EWaS series of conferences started in 2013, when the 1st EWaS Conference was held in Thessaloniki. Associate Professor Vasilis Kanakoudis and Dr. Stavroula Tsitsifli from the University of Thessaly, Volos, Greece, acted as Guest Editors of the nine papers from this conference. The topics dealt in the papers included in the current issue are briefly presented below:

Trichakis et al. (2017) developed and applied a model able to simulate hydrological processes at a Pan-European scale, i.e., the full European continent, divided in $5 \times 5 \mathrm{~km}$ cells. The model is based on coupling of LISFLOOD, which simulates surface hydrological processes, and 2D MODFLOW for groundwater simulation. It can be used for flood forecasting, identification of groundwater recharge/discharge zones and large-scale water resources management. Available meteorological data, aquifer properties from the literature, and observed data of recharge, discharge and hydraulic heads from the Danube river basin were used to check model predictions. A reasonably good agreement between observed and simulated data was achieved. Collection of additional data from various countries and calibration of model parameters are planned to improve the model's predictive ability.

Staboultzidis et al. (2017) investigated the delineation of well head protection areas (WHPAs) for public water supply wells, using a decision support modeling tool, the Wellhead Analytical Element Model (WhAEM). The delineation of WHPAs took place in the basin of Keritis River (near Chania, Crete, Greece). Considering the unique hydrogeology of the area, i.e., location of local heterogeneities, discontinuities, rivers, recharge, no-flow boundaries, etc., three scenarios were modeled corresponding to wet, dry and annually averaged conditions. Worst conditions were in the summer period when the aquifer is heavily pumped. Threatened wells were identified and pollution sources included olive mill wastewater and cemeteries. This methodology is proposed to be used when considering locations of new potentially polluting activities to delineate safety distances from pumped wells.

Caloiero et al. (2017) analyzed the spatial and temporal distributions of rainfall in Calabria region (southern Italy), aiming to verify earlier studies indicating a paradoxical increase in extreme rainfall, despite the decrease in total precipitation in the Mediterranean. Daily precipitation data for the period 1916-2006 were used. The analysis was performed considering the entire region and separately five rainfall zones characterized by different climatic conditions. The results generally showed that Light-Moderate, Moderate-Heavy and Heavy rainfall are the main contributors to the total annual rainfall. Moreover, trend analysis based on the Mann-Kendall test showed a decreasing trend of the higher categories and an increasing trend of the weaker categories.

Volchak and Bulskaya (2017) used mathematical modeling and data for the period 19602009 , and present a quantification of the surface water resources of the Republic of Belarus and a forecast of their transformation in the future under changing climatic conditions. A map of annual river runoff was created, identifying river basins with increasing, decreasing or nochanging runoff regime.

Tigkas et al. (2017) proposed a modification of the Reconnaissance Drought Index (RDI), which is widely and successfully used worldwide for drought characterization. The modified 
index, called Effective Reconnaissance Drought Index (eRDI), aims at improving the ability to assess agricultural drought. The main aspect of eRDI is the substitution of the total precipitation with the effective precipitation, which is the amount of water used by the crops. The use of the eRDI is illustrated through an application in an agricultural area in Greece. The results show that the enhanced index correlates better to crop yield reduction of winter wheat, and is a more reliable and practical tool in assessing drought impacts on rainfed crop yields.

David and Davidová (2017) investigated the relationship between meteorological and hydrological drought in the catchment of Blanice region, using the Standardized Precipitation Index (SPI) and the Streamflow Drought Index (SDI). Data from one hydrological gauging station and from various meteorological stations were used. The two indices were compared to identify the importance of the preceding period length in the occurrence of hydrological drought. The results of performed analyses show the correlation between hydrological and meteorological drought indices which is strongest for the reference periods from 3 to 6 months.

Harbul'áková et al. (2017) investigated the correlation between quality (pollutant concentrations) and quantity (minimum monthly discharge and minimum daily discharge) parameters at three river hydrometric stations, where nitrate nitrogen, ammonium nitrogen and biochemical oxygen demand concentrations were measured during the period 1975-2013. Trends of increasing/decreasing pollutant concentrations in river and trend of minimum monthly discharge and minimum daily discharge were studied. The results showed no correlation between minimum monthly discharge and pollutant concentrations, and between minimum daily discharge (even measured in the same day as the concentration) and pollutant concentration. The authors conclude that water quality problems are dominated by various forms of uncertainties, caused primarily by uncertain hydrological and meteorological conditions. These uncertainties in water quality model parameters and quality models themselves tend to further complicate the problem.

Nautiyal et al. (2017) investigated the adsorption of methylene blue (MB) dye by utilizing biochar generated from residue of Spirulina platensis algae biomass left after simultaneous oil extraction and transesterification for biodiesel production. Batch adsorption experiments were performed to examine the adsorption rate of $\mathrm{MB}$ dye from aqueous solution using four adsorbents, i.e., biochar, commercially available activated carbon, residue biomass and original algal biomass as function of initial dye concentration, adsorbent dosage and $\mathrm{pH}$ of the solution. The results showed that percent removal and specific uptake of MB dye was found maximum for activated carbon, then followed by biochar, residual algae biomass and original algae biomass. The Fruendlich isotherm was found to have the best fit to define the equilibrium characteristics of adsorption. The high adsorption capability of biochar produced from algae biomass left after algae biodiesel production highlights its application as an active adsorbent in wastewater treatment.

Silva et al. (2017) investigated the remediation of chromium (III) contaminated surface water by a permeable barrier. The adsorption capacities of $13 \mathrm{X}$ zeolite and vermiculite were comparatively investigated at different sorbent dosages, $\mathrm{pH}$ and initial $\mathrm{Cr}$ (III) concentration. The equilibrium adsorption studies showed that vermiculite has a higher $\mathrm{Cr}$ (III) removal efficiency in comparison to $13 \mathrm{X}$ zeolite. Fungi isolated from the sediment collected from Tuul River was identified as belonging to the Alternaria alternata species, and showed a good performance in $\mathrm{Cr}$ (III) removal. 13X zeolite showed the best performance in $\mathrm{Cr}$ removal in the permeable barrier reactor tests. The removal of $\mathrm{Cr}$ by the barrier of vermiculite was based exclusively on adsorption, while in $13 \mathrm{X}$ zeolite chromium was removed by a coupled adsorption/precipitation process. 
The present issue of Environmental Processes also includes a collection of six papers initially presented at the 13th International Conference on "Protection and Restoration of the Environment" held from July 3 to 8, 2016, in Mykonos Island, Greece (www.pre13.prd.uth.gr). "Protection and Restoration of the Environment" is a well-known series of international conferences, organized every two years jointly by American and Greek Universities. The first conference of the series was held in Thessaloniki, Greece in 1992. The 13 th Conference of this series was co-organized by Stevens Institute of Technology, USA, the Department of Civil Engineering of the Aristotle University of Thessaloniki, the Department of Civil Engineering of the University of Thessaly and the School of Civil Engineering of the National Technical University of Athens. The conference encourages and promotes the exchange of ideas and knowledge between diverse and interdisciplinary groups of the scientific community concerned with current and emerging issues on protection and restoration of the environment. Dr. Dimitra G. Vagiona, Assistant Professor at Aristotle University of Thessaloniki, Greece, was the Guest Editor of the six papers included in the issue. These papers fall under various general themes, such as Water Resources Management and Contamination Control, Protection and Restoration of Coastal Zone and Open Sea Waters, Waste Minimization and Pollution Prevention, Environmental Impact Assessment and Risk Analysis and Environmental Economics. The issues discussed in the six papers are briefly presented below:

Kalomoiri et al. (2017) developed a system-dynamics framework for a dynamic-risk assessment taking into consideration the mass-depletion processes in a natural attenuation environment. The model allows the dynamic determination of the contaminant exposure levels in the air and groundwater, considering weather fluctuations, and assesses the cancer risk for two exposure routes (air inhalation and water ingestion). From the analysis, it can be concluded that a system-dynamics framework can provide more realistic estimations of the remediation time, contaminant concentration, and overall adverse health effect risk for a receptor.

Töre and Kar (2017) studied waste feeding combinations of miscellaneous industrial sewage sludges in a down draft fluidized bed pilot-scale gasification reactor to maximize energy recovery. Different industrial sewage sludge samples were retrieved from dewatering units of wastewater treatment plants of various industries (textile, dairy, vegetable and nonvegetable oil, glass and metal industries). Three important indicator parameters (moisture, ash and heating value) were used in the analysis to identify the best waste feeding combination of the reactor which would have high gasification efficiency. It turned out that the best feeding combination for sludge gasification reactor is not only the best way to obtain both high energy recovery and low char/tar products but also the best way to minimize industrial sewage sludge before being sent to landfill.

Junakova et al. (2017) assessed the ability of fine- and coarse-grained sediments, dredged from the Klusov water reservoir (Slovakia), to retain phosphorus from overlying surface waters. Sediment particle size, specific surface area, organic content and aluminium content were the main sorption influencing factors. The phosphorus sorption process revealed a very good description by the Langmuir-Freundlich isotherm model. Maxima phosphorus sorption capacities of $325 \mathrm{mg} \mathrm{P} / \mathrm{kg}$ for fine-grained sediment and $207 \mathrm{mg} \mathrm{P} / \mathrm{kg}$ for coarse-grained sediment were found and indicate that both sediment types of the Klusov reservoir can act as efficient traps for phosphorus.

Dagiliūte et al. (2017) evaluated the willingness to pay for the preservation of the current situation and the economic value of authenticity of the Curonian Spit, a protected territory in 
Lithuania that belongs to the UNESCO World Cultural Heritage registry. One of the possible alterations in the study area is the construction of a bridge across a Curonian lagoon in order to facilitate the access to and from the Curonian Spit. The Contingent Valuation Method was used. 217 respondents have participated in the questionnaire survey and the willingness to pay was defined. On the average, respondents were willing to pay 12.92 EUR for the preservation of the authenticity of the site and to receive 18.21 EUR on average for the compensation for the loss of it. The annual estimated authenticity value of Curonian Spit was estimated at more than 4.6 million EUR.

Voukkali et al. (2017) analysed the barriers that arise during the implementation of an Environmental Management System (EMS) in a bakery and confectionary products industry under the framework of ISO 14001:2004. The main problems arising from the implementation of the EMS are related to: non-conformity; corrective and preventing actions; operational controls; monitoring measurements; resources, roles, responsibility and authority; and competence, training and awareness. Although EMS can be used as a tool for any organization to identify, prevent, improve, control and monitor its environmental performance and grow its business competence, its implementation is a complicated task.

Giantsi and Moutzouris (2017) presented an updated formula applied in the design of Low Crested Structures (LCS) used for the protection or eroded shorelines. Two datasets of wave measurements from two different 3D physical models of LCS were analyzed and the transmission coefficients were measured in the sheltered area. Using four different formulae (i.e., the van der Meer and Daemen, the d' Agremond et al., the Goda and Ahrens, and the modified d' Agremond et al. by Giantsi and Moutzouris), the measured and the calculated values of transmission coefficient were evaluated by residual analysis. The formula proposed by Giantsi and Moutzouris was found to satisfy most assumptions of the regression analysis and is proposed to be used in the preliminary design of LCS, providing an acceptable estimation for the wave conditions in the sheltered area of the structures.

\section{References}

Bloutsos AA, Manariotis ID, Yannopoulos PC (2017) Levels of metals Pb, Mn, Fe in the period 2006-2007 in the surface water and groundwater of Alfeios catchment, Greece. Environ Process. https://doi.org/10.1007/s40710-017-0233-z

Caloiero T, Coscarelli R, Ferrari E, Sirangelo B (2017) Temporal analysis of rainfall categories in southern Italy (Calabria region). Environ Process. https://doi.org/10.1007/s40710-017-0215-1

Dagiliūtė R, Žalandauskas M, Sujetovienė G, Žaltauskaite J (2017) Willingness to pay for the authenticity of the Curonian spit. Environ Process. https://doi.org/10.1007/s40710-017-0238-7

David V, Davidová T (2017) Relating hydrological and meteorological drought indices in order to identify causes of low flows in the catchment of Blanice river. Environ Process. https://doi.org/10.1007/s40710-017-0223-1

Giantsi T, Moutzouris CI (2017) Evaluation of wave transmission coefficient at low-crested structures in 3D conditions using residual analysis. Environ Process. https://doi.org/10.1007/s40710-017-0237-8

Gkotsis P, Peleka E, Zamboulis D, Mitrakas M, Tolkou A, Zouboulis A (2017) Wastewater treatment in membrane bioreactors: the use of polyelectrolytes to control membrane fouling. Environ Process. https://doi.org/10.1007/s40710-016-0168-9

Harbuláková VO, Zeleňáková M, Rysulová M, Repel A, Simonová D (2017) Investigation of selected qualitative and quantitative water parameters using correlation analysis. Environ Process. https://doi.org/10.1007/s40710-017-0228-9

Junakova N, Balintova M, Smolakova M (2017) Influence of granularity of sediment from a water reservoir on phosphorus sorption processes. Environ Process. https://doi.org/10.1007/s40710-017-0240-0 
Kalomoiri A, Koutsospyros A, Braida W, Pavlov J (2017) System-dynamics modeling of source mass-depletion and risk-exposure evolution for natural attenuation processes in the vadose zone. Environ Process. https://doi.org/10.1007/s40710-017-0236-9

Kasiteropoulou D, Liakopoulos A, Michalolias N, Keramaris E (2017) Numerical modelling and analysis of turbulent flow in an open channel with submerged vegetation. Environ Process. https://doi.org/10.1007/s40710-017-0235-x

Nautiyal P, Subramanian KA, Dastidar MG (2017) Experimental investigation on adsorption properties of biochar derived from algae biomass residue of biodiesel production. Environ Process. https://doi.org/10.1007/s40710-017-0230-2

Silva B, Tuuguu E, Costa F, Rocha V, Lago A, Tavares T (2017) Permeable biosorbent barrier for wastewater remediation. Environ Process. https://doi.org/10.1007/s40710-017-0220-4

Staboultzidis A, Dokou Z, Karatzas GP (2017) Capture zone delineation and protection area mapping in the aquifer of Agia, Crete, Greece. Environ Process. https://doi.org/10.1007/s40710-017-0221-3

Tigkas D, Vangelis H, Tsakiris G (2017) An enhanced effective reconnaissance drought index for the characterisation of agricultural drought. Environ Process. https://doi.org/10.1007/s40710-017-0219-x

Töre GY, Kar YB (2017) Evaluation of gasification efficiency of miscellaneous industrial sewage sludges in a down draft fludized bed reactor. Environ Process. https://doi.org/10.1007/s40710-017-0227-x

Trichakis I, Burek P, de Roo A, Pistocchi A (2017) Towards a pan-European integrated groundwater and surface water model: development and applications. Environ Process. https://doi.org/10.1007/s40710-017-0216-0

Trikoilidou E, Samiotis G, Tsikritzis L, Kevrekidis T, Amanatidou E (2017) Evaluation of water quality indices adequacy on characterizing the physico-chemical water quality of lakes. Environ Process. https://doi.org/10.1007/s40710-017-0218-y

Volchak AA, Bulskaya IV (2017) Water resources of Belarus under changing climate conditions: current status and prognosis. Environ Process. https://doi.org/10.1007/s40710-017-0231-1

Voukkali I, Lozia P, Pociovalisteanu DM, Zorpas AA (2017) Barriers and difficulties concerning the implementation of an environmental management system in a bakery confectionary industry in Cyprus for 8 years. Environ Process. https://doi.org/10.1007/s40710-017-0242-y

Zotou I, Tsihrintzis VA (2017) The water footprint of crops in the area of Mesogeia, Attiki, Greece. Environ Process. https://doi.org/10.1007/s40710-017-0260-9 